\title{
Свген Борщук
}

доктор економічних наук, професор, професор кафедри менеджменту,

Львівського регіонального інституту державного управління, м. Львів, Україна, е-mail: evhenborshuk@gmail.com, http://orcid.org/0000-0001-8695-6588

\section{Алла Лисачок}

аспірантка кафедри державного управління Львівського регіонального інституту державного управління м. Львів, Украӥна, е-mail:lysachok96@ukr.net, https://orcid.org/0000-0002-5716-487X

\section{ЗЕЛЕНА ЕКОНОМІКА В СИСТЕМІ ЕКОНОМІЧНОЇ БЕЗПЕКИ}

Анотація. Досліджено роль безпеки в екологічній, соціальноекономічній і технологічній сферах людської діяльності життєзабезпечення людини і суспільства в цілому. Доведено, що економічна безпека, як система інструментів і механізмів інституційної взаємодії, має здатність запобігати загрозам або мінімізувати їх вплив на національну економічну систему. Обгрунтовано, що формування системи національної безпеки повинно відбуватись 3 врахуванням сучасних глобальних трендів соціальноекономічного розвитку. На основі системного аналіз сучасних економічних процесів встановлено, що спільним їх недоліком є абсолютизація прибутку, як головної мети економічної діяльності, 3 одночасним нехтуванням соціальних і екологічних наслідків виробничої діяльності. Виконано системний аналіз процесів формування зеленої економіки в контексті забезпечення економічної безпеки в сучасних умовах переходу функціонування національних економічних систем на принципи сталого розвитку, виокремлено визначальні риси «зеленої» економіки. Запропоновано трактувати поняття «зелена економіка» як економічний базис реалізації концепції сталого розвитку на основі більш ефективного ресурсота енергоспоживання, зниження рівнів викидів парникових газів, зменшення шкідливого впливу на довкілля та розвитку соціально інтегрованого суспільства.

Ключові слова: безпека, економічна безпека, розвиток, сталий розвиток, «зелена економіка», «зелені інвестиції». 


\title{
Yevgen Borshchuk
}

\section{Doctor of Economic Sciences, Professor, Professor at the Department of Management, Lviv, Ukraine, e-mail:evhenborshuk@gmail.com, http://orcid.org/0000-0001-8695-6588}

\author{
Alla Lysachok \\ Postgraduate Student at the Department of Public Administration, \\ Lviv, Ukraine, e-mail:lysachok96@ukr.net, \\ https//orcid.org/000-0002-5716-487X
}

\section{GREEN ECONOMY IN THE SYSTEM OF ECONOMIC SECURITY}

\begin{abstract}
The role of safety in the ecological, socio-economic and technological spheres of human activity and the life support of man and society as a whole has been investigated. Reasonably important role of economic security as a determining element of the national security system and in the processes of ensuring normal conditions for the life of society. The approaches to the definition of the concept of «economic security» in the modern conditions of globalization are analyzed. It is proved that economic security, as a system of instruments and mechanisms of institutional interaction, has the ability to prevent threats or minimize their impact on the national economic system. It is substantiated that the formation of the national security system should take place taking into account modern global trends in socio-economic development. Based on a systematic analysis of modern economic processes, it has been established that their common disadvantage is the absolutization of profit as the main goal of economic activity, while neglecting the social and environmental consequences of production activities
\end{abstract}

A systematic analysis of the processes of the formation of a green economy in the context of ensuring economic security in modern conditions of the transition of the functioning of national economic systems to the principles of sustainable development is carried out, the defining features of the «green» economy are highlighted. It is proposed to interpret the concept of «green economy» as an economic basis for the implementation of the concept of sustainable development based on more efficient resource and energy consumption, reduction of greenhouse gas emissions, reduction of harmful effects on the environment and development of a socially integrated society.

It has been proven that green investments allow for a progressive transition to a green economy, and the expansion of green investment can help increase the potential of green industries and the introduction of clean technologies, as well as create new jobs throughout the economy. It is proposed that investments in a green economy be catalyzed and sustained through targeted government spending, policy 
reforms and regulatory changes.

Keywords: security, economic security, development, sustainable development, «green economy», «green investments».

Постановка проблеми. Важливе місце в дослідженнях соціальноекономічних процесів посідає проблема забезпечення безпеки, актуальність якої обумовлена ускладненням характеру соціально-економічних систем, що спричиняє появі значної кількості ризиків соціального, економічного i екологічного характеру на глобальному, національному i регіональному рівнях. Важливе місце в процесах забезпечення безпеки соціальноекономічного розвитку займає економічна безпека, яка, в сучасних умовах, виступає визначальним чинником системи національної безпеки будь-якої держави. Давоський Всесвітній економічний форум, як один 3 найбільш впливових експертних майданчиків 3 питань міжнародної політики та світової економіки у своєму звіті за 2017 рік підтвердив, що на сучасному етапі цивілізаційного розвитку, не тільки зберігаються, але й посилюються ключові ризики в екологічній, соціально-економічної і технологічній сферах людської діяльності.

Аналіз тенденцій соціально-економічного розвитку провідних країн світу підтверджує, що забезпечення економічної безпеки є гарантією незалежності, сталого розвитку та ефективності економіки, соціального благополуччя населення та успішної діяльності суб’єктів господарської діяльності. Формування дієвої системи економічної безпеки держави, галузі, організації забезпечує захищеність від потенційних негативних впливів ринкового середовища, сприяе зростанню конкурентоспроможності національної економіки [1-3].

Неоднозначні економічні процеси, які відбуваються в економіці України, обумовлюють необхідність розробки теоретико-прикладних засад формування системи економічної безпеки держави 3 врахуванням сучасних трендів глобального соціально-економічного розвитку.

Аналіз останніх досліджень і публікацій. Серед українських науковців вагомий внесок у формування теоретико-методологічних засад формування системи економічної безпеки зробили: В.М. Вовк, В.М. Геєць, C.M. Ілляшенко, В.І. Мунтіян, Ю.Г. Лепа, Лисенко, В.С. Пономаренко, Л.Н. Сергєєва. Сучасні тенденції реалізації концепції сталого розвитку у світовій економіці, підходи до формування «зеленої» економіки як ефективного інструменту досягнення цілей сталого розвитку проаналізовано у працях вітчизняних учених: О. Веклич, І. Бистряков, Т. Галушкіна, Б. Данилишин, А. Качинський, Л. Мусіна, В. Потапенко, А. Мартинюк, Ю. Огаренко, та інш.

В цілому, в своїх дослідженнях автори розглядають зелену економіку, як економіку, спрямовану на підвищення добробуту населення і забезпечення соціальної справедливості, а також мінімізацію екологічних екстерналій. Водночас, попри наявність вагомого наукового доробку в аспекті розробки 
ефективних механізмів забезпечення економічної безпеки на основі сталого розвитку і формування зеленої економіки, залишаються невирішеними питання системного аналізу проблем формування зеленої економіки, як інструменту досягнення цілей сталого розвитку.

Метою статті $\epsilon$ системний аналіз процесів формування зеленої економіки в контексті забезпечення економічної безпеки в сучасних умовах переходу функціонування національних економічних систем на принципи сталого розвитку.

Виклад основного матеріалу. В самому загальному випадку безпеку трактують як певний стан і спосіб існування об'єкта безпеки, при якому він спроможний зберігати впродовж певного часу свою сутність (природу) існувати без деградації чи руйнування взагалі. 3 позицій системного аналізу безпека - це характеристика стану і функціонування будь-якої складної системи (біологічної, соціальної, технічної, соціоприродної), що визначає іiі спроможність до самозбереження, iї подальшого існування і розвитку. Таке трактування поняття «безпека» використовують при аналізі функціонування будь-якої складної природно-антропогенної системи в тому числі і при аналізі функціонування економічної системи.

Провідні учені визначають економічну безпеку як найважливішу якісну характеристику економічної системи держави, яка означає іiі здатність підтримувати нормальні умови життедіяльності населення, стійке забезпечення ресурсами для розвитку галузей господарства, та послідовну реалізацію національних інтересів. Крім того, економічна безпека як система інструментів і механізмів інституційної взаємодії, має здатність запобігати загрозам або мінімізувати їх вплив на економіку в цілому і на іiі частини галузі, райони, підприємства [4].

3 позицій системного аналізу можна стверджувати, що економічна безпека - це складна багатогранна економічна категорія, що мас непросту внутрішню структуру. Новікова О.Ф. і Покотиленко Р.В. виокремлюють три ключові вимоги, виконання яких гарантує ефективно функціонуюча система економічної безпеки [5]:

- економічна незалежність, що означає насамперед можливість здійснення державного контролю над національними ресурсами, спроможність використовувати національні конкурентні переваги для забезпечення рівноправної участі у міжнародній торгівлі;

- стійкість і стабільність національної економіки, що передбачає міцність і надійність усіх елементів економічної системи, захист усіх форм власності, створення гарантій для ефективної підприємницької діяльності, стримування дестабілізуючих факторів;

- здатність національної економіки до саморозвитку і прогресу, тобто спроможність самостійно реалізовувати і захищати національні економічні інтереси, здійснювати постійну модернізацію виробництва, ефективну інвестиційну та інноваційну політику, розвивати інтелектуальний і трудовий потенціал країни. 
Особливістю економічної безпеки є те, що вона є фундаментом системи національної безпеки в цілому і виконує чітко визначені функції, несе на собі суттєве функціональне навантаження, є матеріальною основою національної суверенності. Значення економічної безпеки полягає в тому, що виробництво, розподіл i споживання матеріальних благ визначають життєдіяльність суспільства. Не може бути військової безпеки при слабкій і неефективній економіці, так само як не може бути одночасно ні військової, ні економічної безпеки в суспільстві, яке переживає соціальні конфлікти [6-8].

Як зазначають О. Сосновська та М. Житар «...національна економіка стає менш внутрішньо керованою та більш залежною від таких структурних центрів глобалізації як Міжнародний валютний фонд, Світовий банк, Міжнародний банк реконструкції та розвитку, Світова організація торгівлі та інші світові фінансово-економічні організації. За даних умов низькій рівень економічної безпеки національної економіки призводить до зміни розвитку економічних процесів внаслідок порушення стабільності розвитку. Відповідно зменшується рівень ВВП, ефективність розвитку фінансового та реального секторів економіки, купівельна спроможність населення та соціально-економічне благополуччя країни в цілому[9, с. 125-126].

Впродовж тривалого часу в дослідженнях процесів економічного розвитку домінувала модель, яка базувалась на абсолютизації економічного зростання і нехтуванням існуючих соціальних та екологічних проблем. Як наслідок такого підходу, в XX і на початку XXI століття в світі швидкими темпами почали наростати екологічні і соціальні проблеми: зростаючий дефіцит прісної води i продовольства, зміна клімату, скорочення біорізноманіття та лісів, опустелювання та багато інших. На основі аналізі соціально-економічних проблем, ООН виокремила наступні, вирішення яких повинно стати в центрі стратегії цивілізаційного розвитку в XXI ст.:

- понад 40\% світових земельних ресурсів деградує через зниження родючості грунту, iii ерозії та виснаження, що в найближчому майбутньому може привести до втрати 50\% потенційного врожаю;

- майже 1 млрд людей відчувають нестачу чистої питної води;

- 2,6 млрд людей не мають доступу до адекватних санітарних послуг, 1,4 млн дітей, молодше п'яти років, щорічно помирають через брак чистої води і відсутності доступу до необхідних санітарних послуг. У майбутньому нестача води буде лише посилюватися, i через 20 років іï запаси будуть задовольняти лише 60\% світових потреб;

- до 20\% світових виробників зерна нераціонально використовують воду, підриваючи майбутнє зростання сільського господарства i збільшуючи водний дефіцит;

- триває зникнення лісів на планеті: впродовж 2000-2010 рр. площа лісів щорічно зменшувалася на 5,2 млн га.;

- регіонам, на яких проживає третина населення світу, загрожує опустелювання;

- в результаті зміни клімату можуть постраждати близько 2 млрд 
- людей, що живуть на прибережних територіях[10].

Паралельно із загостренням екологічних проблем відбувається загострення і соціальних проблем в глобальному масштабі. На початку XXI ст. на 20\% найбагатшого населення Землі припадало 86\% витрат на споживання, а на 20\% найбіднішого - 1,3\% витрат [11].

Аналіз результатів соціально-економічного розвитку засвідчує, що економічний розвиток, що базується на основі деградації навколишнього середовища i екстенсивному використанню природних ресурсів, не може бути стійким в довгостроковій перспективі. В глобальному масштабі стійкість - це перш за все гармонійний і збалансований розвиток трьох процесів: економічного, соціального та екологічного i без врахування соціальних і екологічних факторів неможливо досягти стійкого розвитку економіки на тривалу перспективу. Тому сьогодні в світі відбуваються активні пошуки нової моделі соціально-економічного розвитку. Найбільш перспективною концепцією цивілізаційного розвитку в XXI ст. $є$ концепція сталого розвитку, яка була запропонована на Міжнародній конференції ООН 3 навколишнього середовища і розвитку (Ріо-де-Жанейро, 1992p.). Вона є результатом науково-прикладного пошуку визначення меж господарської діяльності людства, що визначаються 3 позицій екологічних, ресурсносировинних і демографічних чинників цивілізаційного розвитку. Головним результатом Конференції стало визнання необхідності міждисциплінарного підходу до вирішення глобальних проблем розвитку, які в своїй основі мають еко-соціо-економічний характер. Поняття «сталий» 3 позицій економічного зростання означає, що економічні драйвери забезпечують соціально-екологічну стійкість розвитку на тривалий термін 3 врахуванням інтересів сучасних і майбутніх поколінь.

Перехід цивілізаційного розвитку на принципи сталого розвитку обумовлює необхідність модернізації та екологізації економіки, причому це вимагає не просто зростання інвестицій задля вирішення екологічних проблем, але, перш за все, соціальних новацій, зміни пріоритетів і цілей розвитку цивілізації в цілому. Необхідно зазначити, що вже сьогодні в світі відбуваються певні позитивні структурні зміни. Це перш за все збільшення ефективності використання ресурсів, революційні перетворення в сфері енергетики, використання в виробничих процесах замкнутого циклу, коли відходи знову надходять на виробництво в якості сировини.

Конкретні шляхи забезпечення сталого розвитку відображено у важливих документах ООН, прийнятих за останній час, серед яки ми виокремлюємо:

- «Майбутнє, якого ми хочемо» (2012): визначає перспективи людства в XXI ст. на основі концепції сталого розвитку, базою якого повинна стати зелена економіка [12];

- «Порядок денний в області сталого розвитку на період до 2030року» (2015) визначає Цілі сталого розвитку ООН на період 2015-2030 pp. [13];

- «Паризька кліматична угода» (2015), що визначає пріоритети боротьби 
3 кліматичною загрозою в світі і всіх країнах до 2030-2050 рр., що важливо для переходу до сталого розвитку. На початку XXI ст. однією з головних глобальних екологічних проблем було визнано зміну клімату. У 2015 році на Паризькій конференції з питань клімату було прийнята нова міжнародна багатостороння угода з протидії зміні клімату, метою якої є не допущення підвищення глобальної приземної температури в цьому столітті вище $2^{\circ} \mathrm{C}$ i намагання сторін не перевищити температурну межу на 1.5 C. [14].

Впродовж тривалого часу в світовій економічній системі домінували ринкові механізми регулювання економічних процесів, що призвело до виснаження запасів природного капіталу та енергетичних ресурсів, масштабної бідності у ряді країн, браку прісної води та продовольства, збільшення економічного та соціального "розриву” з-поміж країн та регіонів світу, а також загострення екологічних проблем у національних і глобальних масштабах. Все це обумовило необхідність переглянути різні аспекти взаємодії суспільства, навколишнього середовища та економіки, що знайшло своє відображення формуванні концепції сталого розвитку, яка була визнана стратегією цивілізаційного розвитку на XXI ст. Інструментом досягнення цілей сталого розвитку ООН визнає «зелену» економіку.

В контексті забезпечення переходу функціонування соціальноекономічних систем на принципи сталого розвитку в межах економічної науки йде пошук нових моделей економіки, що враховують екологічні i соціальні фактори: зелена економіка (green economy), економіка на основі зеленого зростання (green growth), низьковуглецева економіка (low-carbon economy), біоекономіка (bioeconomy), синя економіка (blue economy), соціально-орієнтована економіка тощо.

Не дивлячись на те, що поняття «зеленої» економіки все частіше використовується у ключових документах міжнародних організацій, в стратегічних концепціях глобальних стратегій соціально-економічного розвитку, єдине загальноприйняте на міжнародному рівні визначення «зеленої» економіки відсутнє. Так, досить широко трактує це поняття ЮНЕП: зелена економіка - це економіка, яка підвищує добробут людей i забезпечує соціальну справедливість, і при цьому істотно знижує ризики для навколишнього середовища і його деградацію. Тобто, під поняття «зелена економіка» підпадають всі вищезгадані моделі економіки.

Зелена економіка, ефективно використовуючи ресурси і задовольняючи потреби всього суспільства, повинна використовувати державні і приватні інвестиції з метою зменшення викидів парникових газів i біосферного забруднення взагалі, забезпечує підвищення ефективності використання енергії та ресурсів і запобігання незворотних втрат біорізноманіття та екосистемних послуг. Ці інвестиції в зелену економіку необхідно каталізувати i підтримувати за допомогою цільових державних витрат, реформ в області політики i зміни регулювання. Такий шлях розвитку повинен зберігати, збільшувати i, де це необхідно, відновлювати природний капітал, як найважливіший економічний актив і джерело суспільних благ, 
особливо для бідних верств населення, джерела доходу і захищеність яких залежать від природи [15].

Європейське агентство з охорони навколишнього середовища дає більш спрощене трактування “зеленої” економіки, визначаючи іiі як політику та інновації, що дають змогу щороку отримувати більше цінності, зберігаючи природні системи, які їі підтримують [16]. Під «зеленою» економікою часто мається на увазі тільки «зелений» бізнес, який охоплює виробництво різного роду очисного обладнання, утилізацію вторинних ресурсів і відходів, який надає екологічні послуги та ін. При такому трактуванні «зелена» економіка представляється лише частиною «коричневої» економіки. Очевидно, що «мирне» співіснування «зеленої» та природозатратної «коричневої» економіки навряд чи можливо. Наприклад, збереження трендів на екстенсивний розвиток енергетики і металургії, навіть при найшвидшому розвитку «зеленого» бізнесу, призведе до збереження експортно-сировинної і нестійкою моделі економіки України.

В цілому, поняття “зелена” економіка розглядається як економічний базис реалізації концепції сталого розвитку на основі більш ефективного ресурсо- та енергоспоживання, зниження рівнів викидів парникових газів, зменшення шкідливого впливу на довкілля та розвитку соціально інтегрованого суспільства. Реалізація будь-яких економічних проектів потребує чималих інвестицій, які в загальному трактуються як відносно «безпечне» вкладення капіталу, яке здійснюється в об'єкт інвестування (виробництво, послуги, технології, нерухомість, фінансові продукти тощо) сьогодні з метою отримання вигід - економічних переваг - у майбутньому. «Зелені» інвестиції $\epsilon$ тією сполучною ланкою, яка дозволяє здійснити поступальний перехід до «зеленої» економіки, а розширення обсягів «зеленого» інвестування може сприяти зростанню потенціалу «зелених» галузей та запровадженню чистих технологій, а також забезпечити створення нових робочих місць у межах усієї економіки. «Зелене» інвестування $є$ значимим сегментом інвестиційного ринку, який 3 кожним роком поширюється на дедалі більшу кількість країн, а такі фінансові інструменти як «зелені» кредити та облігації, «зелені» кредитні лінії (є основним джерелом довгострокового фінансування, особливо у сфері енерго- та ресурсоефективності), гранти та структуровані фонди «зелених» інвестицій демонструють поступальний розвиток. Але «озеленення» економіки вимагає «переформатування» поточних і майбутніх інвестицій, додаткових витрат за межами звичайного підходу. «Зелені» інвестиції сприяють зменшенню викидів парникових газів, раціоналізації поводження 3 відходами, ефективному управлінню стічними водами та протидії різним екологічним ризикам, підтримуючи стабільність екосистем, впроваджуючи енергоефективні заходи та розвиваючи відновлювану енергетику та екологічно безпечні технології. Такі інвестиції можуть позитивно впливати на енергетичний баланс країни, підвищувати рівень енергоефективності економіки та конкурентоспроможності вітчизняної продукції на світових 
ринках, а також платоспроможність населення, зокрема за житловокомунальні послуги. Вони здатні створювати нові («зелені») робочі місця та забезпечувати гідну заробітну плату працівникам [17, с. 82].

Аналіз реалізації «зеленого» інвестування в Україні засвідчив, що, незважаючи на широке декларування щодо підтримки «зелених» бізнес проектів, реальна практика показує, що ці пріоритети нелегко втілюються у конкретних бізнес-проектах. До «зелених» проектів відносять такі, що відповідають наступним напрямам:

- відновлювані джерела енергії;

- розвиток альтернативних джерел енергії;

- ефективне використання енергії;

- підвищення теплоізоляції житлових будинків;

- утилізація та переробка відходів;

- екологічно чистий транспорт;

- ефективне використання земельних ресурсів;

- збереження флори і фауни, водних ресурсів;

- адаптація до змін клімату [18].

Серед головних перешкод на шляху «зеленого» інвестування бізнес проектів підприємці визначають:

- відсутність надійного та ефективного інституційного та законодавчого забезпечення;

- більший ризик та відносно низький прибуток від «зеленого» інвестування;

- висока вартість «зелених» інвестицій;

- «незрілість» ринку «зелених» інвестицій.

Необхідно зазначити, що, відповідно до підсумкового документу Конференції ООН зі сталого розвитку «Майбутнє, якого ми хочемо» $($ Pio+20), зелена економіка розглядається як один з важливих інструментів забезпечення сталого розвитку, яка зміцнить здатність держав раціонально використовувати природні ресурси 3 меншим негативним впливом на навколишнє середовище, підвищить ефективність використання ресурсів та зменшить кількість відходів. При цьому, концепція зеленої економіки не замінює собою концепцію сталого розвитку, однак все більш загальновизнаним стає твердження, що досягнення сталості розвитку багато в чому залежить від формування саме зеленої економіки. У цьому сенсі зелена економіка є основою сталого розвитку, і сама вона заснована на його принципах. 3 цих позицій визначальними рисами зеленої економіки є:

- ефективне використання природних ресурсів;

- збереження і збільшення природного капіталу;

- зменшення забруднення;

- низькі вуглецеві викиди;

- запобігання втрати екосистемних послуг та біорізноманіття;

- зростання доходів і зайнятості.

Незважаючи на позитивні причини, які повинні сприяти переходу на 
принципи «зеленої» економіки? в Україні, існують бар'єри, що заважають цьому процесу. Серед них можна виділити:

- відсутність достатнього політичного інтересу і політичної волі до реалізації технологій «зеленої» економіки, наприклад, переробці відходів, впровадження найкращих доступних технологій;

- інертність трансформації економічної моделі (від експортносировинної до інноваційної), а також відсутність можливостей або бажання змінити ситуацію в бізнес-середовищі;

- недостатня актуальність екологічної проблематики в свідомості осіб, які приймають рішення.

На рівні системи державного управління повинно бути усвідомлення того, що «зелені» трансформації повинні охоплювати всю економіку, i процеси екологізації можуть бути по-справжньому ефективними тільки на макрорівні.

Висновки. Світові тенденції соціально-економічного розвитку в кінці XX ст.. і на початку XXI ст. засвідчують необхідність «озеленення» світової економіки, що обумовлено необхідністю збалансування суспільних економічних потреб 3 потребою постійного відновлення i збереження довкілля. Функціонування «зеленої економіки» охоплює як процеси виробництва так i споживання i спрямовано на забезпечення сталого розвитку, досягнення цілей сталого розвитку, проголошених в декларації тисячоліття. Поняття «зелена економіка» не можна розглядати як синонім поняття «сталий розвиток». Сталий розвиток є значне ширша категорія а «зелена економіка» $є$ інструментом досягнення цілей сталого розвитку.

\section{Jimepamypa:}

1. Економічна безпека підприємства: сутність та механізм забезпечення : монографія/ Г. В. Козаченко, В. П. Пономарьов, О. М. Ляшенко. - Київ: Лібра, 2003 - 280 с. $464 \mathrm{c}$.

2. Мунтіян В.І. Економічна безпека України / В.І. Мунтянін. - Київ : КВІЦ, 1999. -

3. Васильців Т. Г. Економічна безпека підприємництва України: стратегія та механізми зміцнення: монографія / Т. Г. Васильців. - Львів : Арал, 2008. 384 с.

4. Моделювання економічної безпеки: держава, регіон, підприємство / Геєць В.М., Клебанова Т.С., Черняк О.І., та ін..; за ред. В.М. Гейця. Харків : ВД «ІНЖЕК», 2006. - 240 с.

5. Новікова О.Ф. Економічна безпека: концептуальне визначення та механізм забезпечення : монографія. / О.Ф. Новікова, Р.В. Покотиленко. - Донецьк : Ін-т економіки промисловості НАН України, 2006. - 407 с.

6. Економічна безпека України: проблеми та пріоритети зміцнення : монографія. 3.С. Варналій, Д.Д. Буркальцева, С.О. Саєнко. - Київ : Знання України, 2011. 299 с.

7. Кавун С В. Система економічної безпеки: методологічні та методичні засади : монографія. / С.В. Кавун. - Харків : ХНЕУ, 2009. 303 с.

8. Гарічева, С.Ю. Система економічної безпеки підприємства [Електронний ресурс] / С.Ю. Гарічева // Менеджмент: розвиток, теорія та практика. - 2012. Режим доступу: http://thesis.at.ua/publ/menedzhment_rozvitok_teorija_ta_praktika/garicheva_s_ju_sistema_ekon omichnoji_bezpeki_pidpriemstva/5-1-0-52.

9. Сосновська О. О. Економічна безпека підприємства: сутність та ознаки 
забезпечення /О.О. Сосновська, М.О. Житар // Облік і фінанси. - 2018. - № 3. С.124-132.

10. ПРООН. Отчет о человеческом развитии за 2011 год: устойчивость и справедливость - лучшее будущее для всех. [Електронний ресурс]. Нью-Йорк.-2011.Режим доступу: http://hdr.undp.org/en/content/human-development-report-2011.

11. UNEP, 2011. Decoupling natural resource use and environmental impacts from economic growth [Електронний pecypc]. Retrieved from: https://www.resourcepanel.org/reports/decoupling-natural-resource-use-and-environmentalimpacts-economic-growth.

12. Сайт ООН. Будущее, которого мы хотим [Електронний ресурс]. Итоговый документ Конференции ООН по устойчивому развитию. Рио-де-Жанейро, Бразилия. 2022 июня 2012 г. $\mathrm{OOH}, 2012 . \quad$ Режим доступа: https://undocs.org/pdf?symbol=ru/A/CONF.216/L.1

13. Сайт Генеральной Ассамблеи ООН. Преобразование нашего мира: Повестка дня в области устойчивого развития на период до 2030 г. ООН, Нью-Йорк, сентябрь 2015 [Електронний ресурс]. Режим доступа: http://docs.cntd.ru/document/420355765

14. Сайт Генеральной Ассамблеи ООН. Принятие Парижского соглашения. Конференция Сторон. Двадцать первая сессия. Париж, 30 ноября - 11 декабря 2015 г. Рамочная конвенция Организации Объединенных Наций об изменении климата. ООН, 2015 [Електронний ресурс]. Режим доступа: https://unfccc.int/resource/docs/2015/cop21/rus/109r01r.pdf

15. UNEP, 2011, Towards a Green Economy: Pathways to Sustainable Development and Poverty Eradication [Електронний pecypc]/ A Synthesis for Policy Makers. Режим доступу: www.unep.org/greeneconomy.

16. Green economy [Електронний ресурс] - European Environmental Agency. Режим доступу: https://www.eea. europa. eu/themes/ economy/intr.

17. “Зелені” інвестиції у сталому розвитку: світовий досвід та український контекст [Електронний ресурс] Київ : Заповіт, 2019. Режим доступу: https://razumkov. org.ua /uploads /article/2019_ZZELEN_ INVEST.pdf

18. Фролов А. Світовий досвід організації ринку зелених облігацій: практичні поради для України [Електронний ресурс] / А. Фролов, К. Гура // ECOBUSINESS. Екологія підприємства. - 2019. - Режим доступу: http:// ecolog-ua.com/articles/svitovyydosvid-organizaciyi-rynkuzelenyh-obligaciy-praktychni-porady-dlya-ukrayiny

\section{References:}

1. Kozachenko, G.V., Ponomarev, V.P. \& Lyashenko, O.M. (2003). Ekonomichna bezpeka pidpryiemstva: sutnist ta mekhanizm zabezpechennia [Economic security of the enterprise: essence and mechanism of provision]. Kyiv: Libra [in Ukrainian].

2. Muntian, V.I. (1999). Ekonomichna bezpeka Ukrainy [Economic security of Ukraine]. Kyiv : KVITs [in Ukrainian].

3. Vasyltsiv, T.G. (2008). Ekonomichna bezpeka pidpryiemnytstva Ukrainy: stratehiia ta mekhanizmy zmitsnennia [Economic security of entrepreneurship of Ukraine: strategy and mechanisms of strengthening]. Lviv:Aral [in Ukrainian].

4. Geets, V.M., Klebanova, T.S., Chernyak, O.I. et al. (2006). Modeliuvannia ekonomichnoi bezpeky: derzhava, rehion, pidpryiemstvo [Modeling of economic security: state, region, enterprise] Kharkiv: VD «INZhEK» [in Ukrainian].

5. Novikova, O.F. \& Pokotylenko, R.V. (2006). Ekonomichna bezpeka: kontseptualne vyznachennia ta mekhanizm zabezpechennia [Economic security: conceptual definition and support mechanism] : Donetsk: Institute of Industrial Economics of the National Academy of Sciences of Ukraine [in Ukrainian]. 
6. Varnalii, Z.S. Burkaltseva, D.D. \& Saienko, S.O. (2011). Ekonomichna bezpeka Ukrainy: problemy ta priorytety zmitsnennia [Economic security of Ukraine: problems and priorities of strengthening]. Kyiv: Znannia [in Ukrainian].

7. Kavun, S.V. (2009). Systema ekonomichnoi bezpeky: metodolohichni ta metodychni zasady: [System of economic security: methodological and methodical principles]. Kharkiv: KhNEU [in Ukrainian].

8. Haricheva, S.Iu. (2012). Systema ekonomichnoi bezpeky pidpryiemstva [System of economic security of enterprises]. Menedzhment: rozvytok, teoriia ta praktyka - Management: development, theory and practice. Retrieved from http://thesis.at.ua/publ/menedzhment_rozvitok_teorija_ta_praktika/garicheva_s_ju_sistema_ekon omichnoji_bezpeki_pidpriemstva/5-1-0-52 [in Ukrainian].

9. Sosnovska, O. O. \& Zhytar, M.O. (2018). Ekonomichna bezpeka pidpryiemstva: sutnist ta oznaky zabezpechennia [Economic Security of Entrepreneurship: Essence and Maintenance Service]. Oblik i finansy - Accounting and finance, 3, 124-132 [in Ukrainian].

10. Sait PROON. Otchet o chelovecheskom razvytyy za 2011 hod: ustoichyvost y spravedlyvost - luchshee budushchee dlia vsekh. [Human Development Report 2011: Sustainability and justice are the best future for all.]. Retrieved from http://hdr.undp.org/en/content/human-development-report-2011 [in Russian].

11. UNEP (2011). Decoupling natural resource use and environmental impacts from economic growth. Retrieved from https://www.resourcepanel.org/reports/decoupling-naturalresource-use-and-environmental-impacts-economic-growth [in English].

12. Sait OON (2012). Budushchee, kotoroho mы khotym [The future we want]. Ryo-deZhaneiro, Brazylyia. Retrieved from https://undocs.org/pdf?symbol=ru/A/CONF.216/L.1 [in Russian].

13. Sait Heneralnoi Assambley OON (2015). «Preobrazovanye nasheho myra: Povestka dnia v oblasty ustoichyvoho razvytyia na peryod do $2030 \mathrm{~h}$ » [Transforming our world: The 2030 Agenda for Sustainable Development United Nations]. Retrieved from http://docs.cntd.ru/document/420355765 [in Russian].

14. Sait Heneralnoi Assambley OON. [Sait of the UN General Assembly]. Retrieved from https://unfccc.int/resource/docs/2015/cop21/rus/109r01r.pdf

15. UNEP (2011). Towards a Green Economy: Pathways to Sustainable Development and Poverty Eradication. Retrieved from www.unep.org/greeneconomy [in English].

16. Sait European Environmental Agency. Green economy. Retrieved from https://www.eea. europa. eu/themes/ economy/intr.

17. "Zeleni" investytsii u stalomu rozvytku: svitovyi dosvid ta ukrainskyi kontekst [«Green» investments in sustainable development: world experience and Ukrainian context]. Kyiv : Zapovit, 2019. Retrieved from https://razumkov. org.ua /uploads /article/2019_ZELEN_ INVEST.pdf [in Ukrainian].

18. Frolov, A. \&Hura, K. (2019). Svitovyi dosvid orhanizatsii rynku zelenykh oblihatsii: praktychni porady dlia Ukrainy [World experience in organizing the market of green bonds: practical advice for Ukraine]. Ekolohiia pidpryiemstva - Ecology of the enterprise. Retrieved from http:// ecolog-ua.com/articles/svitovyy-dosvid-organizaciyi-rynkuzelenyh-obligaciypraktychni-porady-dlya-ukrayiny [in Ukrainian]. 